\title{
特性的自己効力感とネガティブな出来事に対する原因帰属 および対処行動
}

\author{
三 宅 幹子1) \\ 広島大学大学院教育学研究科
}

特性的自己効力感（GSE）の高さにより，ネガティブな出来事に対する原因帰属と対処行動にどのよ うな違いがみられるかを検討した．238名の大学生に，2つのネガティブな場面を想定させ，それに対 する原因帰属と, どのような対処行動をとるかを評定させた. その後, GSE 尺度に評定させ，その尺度 值をもとに被験者を高群と低群に分けた．各場面を重要であると評定した者のデータ（両場面とも 166 名）を用いて分析した結果，高群・低群間の原因帰属のパターンの違い方は，男性と女性で異なってい た．男性においては，高群は低群よりも内的で統制可能な要因に帰属する傾向がみられたのに対し，女 性においては，高群は低群に比べ内的な要因には帰属しない傾向がみられた．また，男女とも高群のほ うが次回に対する課題固有の自己効力感や積極的な対処行動の評定値は高く, 帰属傾向の群間差がこれ らの群間差に結びついていると考えられる.

キーワード : 特性的自己効力感, ネガティブな出来事, 原因帰属, 対処行動

\section{問 題}

自己効力感（self-efficacy）とは，ある状況にお いて，ある結果を達成するために必要な行動を自 分がうまくできるかどうかの予期であり（Bandura， 1977)，ある課題に対する自己効力感を自分がど の程度持っているか（perceived self-efficacy）が, その個人の行動の変容を予測することが知られて いる（坂野，1989; 坂野・東條，1986）。自己効力 感には，2つの水準があり（坂野・東條, 1993）, 1 つは臨木 ・教育場面における研究でよく取り上 げられている，課題や場面に特異的に影響を及ぼ す自己効力感（task specific self-efficacy: 以下 SSE

1) 本研究を行なうにあたり，ご指導下さいました，広島大 学教育学部教授松田文子先生, 助教授湯澤正通先生に厚 く御礼申し上げます。また, 調査の実施にご尽力下さっ た安田女子大学助教授池田智子先生, 調査にご協力下 さった学生の皆様に深く感謝致します。
とする), もう 1 つは具体的な個々の課題や状況 に依存せずに, より長期的に，より一般化した日 常場面における行動に影響する自己効力感である (generalized self-efficacy: 以下 GSE とする)，後者 は, ある種の人格特性的な認知傾向とみなすこと ができるので, 特性的自己効力感と呼ばれること もある (成田・下仲・中里・河合・佐藤・長田, 1995). Sherer, Maddux, Mercandante, Prentice-Dunn, Jacobs \& Rogers（1982）によれば，GSEは過去 の成功と失敗の経験から形成され, 特定の状況だ けでなく未経験の新しい状況においても適応的に 処理できるという期待（SSE）に影響を与えると いう。また，GSEには個人差が想定されている が，このことは，GSEの高低が SSEを高く認知 したり低く認知したりする傾向の個人差を生み出 すことにより，個人の行動全般にわたって影響す る可能性があることを示す（成田ほか，1995）。 
ところで，GSE と実験室課題に対する SSE と の関連について実証的に検討した三宅（2000）は, 課題の遂行成績のフィードバックとしてネガティ ブな社会的比較情報を与えられた場合のSSEの 変容傾向には，GSEの高低による違いが見られ， GSE 高群は GSE 低群よりも高い SSE を示すこと を報告している，つまり，GSEはSSEの変容を 規定する要因であり，GSE 高群は GSE 低群より もネガティブな社会的比較情報によるダメージを 受けにくいといえる.

また, 課題の遂行成績のフィードバック情報 （結果についての情報）がSSEの変容に及ぼす影 響は，遂行結果がどのように原因帰属されるかに よってある程度規定されることが知られている (Bandura, 1986; Silver, Mitchell \& Gist, 1995)。例 えば，三宅（2000）のように，課題の遂行成績に ついてネガティブなフィードバック情報を与えら れた場合にも，その結果を自分の力で統制できる 要因, すなわち, 内的かつ統制可能な要因に帰属 した場合は，自分次第でその結果を変容させるこ とができると認知されるため，SSEにはネガティ ブなフィードバック情報の悪影響はみられにく い，一方，自分の力では統制できない要因に帰属 した場合は，SSEにネガティブなフィードバック の悪影響が反映されやすい。原因帰属の統制可能 性次元については, 内的で統制可能な要因への原 因の帰属がその後の達成期待と強く関係し，外的 で統制不可能な要因への原因の帰属は，期待の低 下と関係する（Forsyth \& McMillan, 1981）など, この次元が将来の達成期待に強い影響を及ぼすこ とを示す知見が得られている。これより，上記の 三宅（2000）において，GSE 高群は，GSE 低群 と比較して, 内的で統制可能な要因により強く帰 属していたと推測される.

GSE と原因帰属との関連について示唆を与え る研究として, Locus of control (Rotter, 1966) に おける内的統制型（internal control）と外的統制 型（external control）を測定する尺度である，
Internal-External スケールと特性的自己効力感 （GSE）尺度との相関を検討した，藤田・笹川 （1991）やSherer et al. (1982) などが挙げられる. 彼らの研究では両者の間に有意な相関がみられ, GSEが高い者ほど内的統制型であることが示さ れている.内的統制型の者は外的統制型の者に比 へ，行動によって引き起こされた結果を自分自身 に随伴しているととらえ，周囲の環境に対して統 制可能感をいだいているという（藤田・笹川, 1991）。これより，内的で統制可能な原因への帰 属と GSEの高さとの関連が想定される.

ところで，ネガティブなフィードバックの影響 を受けにくい原因帰属のパターンとして，上記以 外に，ネガティブな結果を自己の外部，或いは外 的でかつ不安定な要因に帰属するパターンも考え られる。これは，上述した内的で統制可能な要因 への原因帰属が努力量の増加へとつながりやすい 適応的なものであるのに比べ，ネガティブな結果 を自己に帰属しないことによって次回に対する期 待の水準が下がるのを食い止める自己保護的 (self-protecting) な帰属パターンである。この自 己保護的な帰属パターンは，当該課題に対する SSEの高い者がネガティブなフィードバックを受 けた場合に顕著にみられることが知られている (Silver, Mitchell \& Gist, 1995). GSE と原因帰属と の関連を検討した Watt \& Martin（1994）では, GSEの高低に関わらず，自分に都合のよいバイ アス（self-serving bias; 成功を自己に帰属する自 己高揚バイアスと，失敗に対する自己の責任を否 定する自己保護バイアスからなる）が顕著で, GSEの高低による原因帰属の違いはみられてい ないが,この点について検討した研究は少なく， 再度検討してみる余地がある.

以上の知見をまとめると，ネガティブな社会的 比較情報を含むフィードバックを与えられる状況 下で，高 GSE 群は，低 GSE 群と比較して，内的 で統制可能な要因への原因帰属が顕著な帰属パ ターン（適応的な原因帰属パターン）か，または， 
自己外の要因への原因帰属が顕著な帰属パターン （自己保護的な原因帰属パターン）のいずれかを 示すと予想される，そして，このような帰属傾向 の違いに伴い, ネガティブな出来事への対処行動 も異なると考えられる。すなわち，GSE群間の 差が, GSE 高群のより適応的な帰属パターンに よるものである場合には, GSE 高群は自己の統 制可能性を強く認知しているため, 低群よりも能 動的で積極的な対処行動をとり，消極的な対処行 動よりも積極的な対処行動において GSE 群間差 が顕著になると予想される，そこで，積極的対処 行動, 消極的対処行動の 2 カテゴリーの対処行動 を取り上げ，これらにおけるGSE 群間差を検討 する。

本研究では, 三宅（2000）でみられた SSEに おける GSE 群間差のメカニズムを検討するため, 社会的比較情報を含むネガティブな出来事に対す る原因帰属と対処行動における GSE 群間差を, 上記の観点から検討する，また，調查方法に関し ては，実際に経験したネガティブな出来事を回想 してもらう方法は, その際にとつた行動次第でネ ガティブな出来事に対する認知が後付け的に解釈 し直される可能性があり, 認知傾向における群間 差を検討するには不向きであろうと考えられた. そこで，そのような影響を除いて検討するため， 場面想定法を用いた。

\section{方 法}

\section{被調查者}

地方小都市の国立大学の 3 年生, 238 名（男性 87 名，女性 151 名）であった.

\section{手続き}

場面想定法を用いた，無記名式の質問紙形式の 調査を集団で実施した。

\section{質問紙の構成}

質問紙の内容は，ネガティブな場面を説明する 文章とその場面についての評定項目とのセットが $2 つ$, 特性的自己効力感尺度（以下, GSE 尺度）
（成田ほか，1995）であった。

ネガティブな場面の提示 大学生が日常生活で 遭遇しやすいネガティブな出来事として，「講義 の単位を落としてしまう場面（試験場面）」と 「重要なレポートに低い評価をつけられてしまう 場面（レポート場面）」の 2 つ場面を用いた (Table1の上部に示す). 2つの場面を用いたのは, 結果の一般性, 安定性を増すためである. 両場面 とも文章中には, 被調査者が劣位であることを示 す社会的比較情報が含まれていた，場面を説明す る文章を順に提示し，それぞれの場面に自分自身 が直面していることを想定しながら読み，あとの 質問に答えるように文章で教示した，場面を説明 する文章の後には，それぞれ，以下の，原因帰属 の評定項目, 対処行動の評定項目, SSEの評定項 目，場面の重要性の評定項目を提示した。被調査 者の約半数に試験場面, レポート場面の順序で, 残りの半数には逆の順序で提示した.

原因帰属の評定項目 中学生を対象に場面想定 法を用いて試験の失敗に対する原因帰属を測定し ている，Hayamizu (1997) で使用された 7 項目の うち, 大学生では考えにくい1項目（「parent's

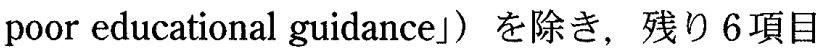
を本研究で使用した場面に適合するよう書き換 え, Table 1 に示す 6 つの項目を作成した. 「努力 が足りなかった」、「試験勉強のし方（レポートへ の取り組み方）が悪かった」，「能力が足りなかっ た」が内的な帰属因についての項目である.内的 な帰属因のうち, 前者 2 つが統制可能な帰属因に ついての項目であり，最後の 1 つが統制不可能な

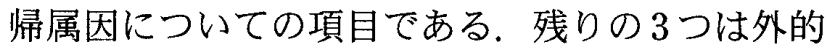
な帰属因についての項目である．これら6つの項 目について, 各場面の出来事にそれらがどの程度 影響していると思うかを，「非常に影響している (5)」から「全く影響していない(1)」までの5段 階で評定させた。

対処行動の評定項目 対処行動の評定項目も, Hayamizu（1997）を参考に作成した. Hayamizu 
Table 1 場面を説明する文章，および原因帰属と対処行動の評定項目 ${ }^{a)}$

\begin{tabular}{l}
\hline 試験場面 \\
\hline 《場面を説明する文章》 \\
「期末試験ができていれば単位は取れる」と聞いていた講義 \\
の期末試験を受けたが, 単位を落としてしまった. 周囲の人 \\
たちに聞いてみたところ, ほとんどの人が単位を取れており, \\
単位が取れなかつたのは少人数のようであった.
\end{tabular}

\section{《原因帰属の評定項目》b)}

・努力が足りなかった（内的・統制可能)

・試験鬿強のし方が悪かった。（内的・統制可能）

・能力が足りなかった（内的・統制不可能）

・自分にとっては, 期末試験の問題が難しかった（外的）

・たまたま運が悪かった。（外的）

・担当教官が悪かった。（外的）

\section{《対処行動の評定項目》}

\section{<積極的対処行動>}

・これからは，講義の単位を取るために，今までよりももっ と努力する。

・他の講義についても，単位を落とさないためにはどう取り 組めばよいか，対策をよく考える。

・単位を落とした理由をはっきりさせようとする.

\section{<消極的対処行動>}

・なにか，気晴らしになることをする。

・単位を取るのが難しそうな講義は，なるべく選択しないよ うにする。

・嫌なことなのであまり深く考えないようにする.
レポート場面

\section{《場面を説明する文章》}

必修の授業の成績に影響する重要なレポートが返却され た．自分のレポートの評価は低く“C”であった，まわりの 友達は，ほとんど“A”であり，彼らの評価と比べてみても， 自分のレポートの評価は，かなり低かった。

\section{《原因帰属の評定項目》b)}

・努力が足りなかった. (内的・統制可能)

・レポートへの取り組み方が悪かった。（内的・統制可能）

・能力が足りなかった（内的・統制不可能)

・自分にとっては, レポートの課題が難しかった. (外的)

・たまたま運が悪かった。（外的）

・担当教官が悪かった（外的）

\section{《対処行動の評定項目》}

\section{<皘極的対処行動>}

・次回のレポートが課されたら,レポートをしあげるのに, 今回よりもっと努力することにする。

・次回のレポートにはどう取り組んだらいいか，対策をよく 考える.

・評価が低かった理由をはっきりさせようとする。

\section{<消極的対処行動>}

・なにか, 気晴らしになることをする。

・今後, このようなレポートが課される講義はなるべく選択 しないようにする.

・嫌なことなのであまり深く考えないようにする。 a）評定項目の順番は内容が偏らないように変えてある.

b) 実際の質問紙には（）内は記入していない。
（1997）では，9つの対処行動についてどの程度 それらを行なうかを評定させ，評定值を因子分析 $し て 「$ active coping behaviors $\lrcorner, 「$ passive coping behaviors $\lrcorner$, 「maladaptive coping behaviors」の 3 因子を抽出している．本研究では，そのうちの 「active coping behaviors $\_\lceil\text {passive coping behav- }$ iors」を対処行動カテゴリとして採用し，両因子 に負荷の高い項目を参考に，本研究で使用した場 面，および，調査対象とする大学生に適合するよ うに, Table 1 の最下欄に示す, 積極的対処行動 に関する 3 項目と消極的対処行動に関する 3 項目 を作成した．これら 6 つの項目について，どの程 度そうすると思うかを，「非常にそうすると思う (5)」から「全くそうすると思わない (1)」まで
の 5 段階で評定させた.

SSEの評定項目 各場面について, 下記の評 定項目を用いて, 次回またそのような出来事に遭 遇した際の自己効力感（SSE）を，「非常にそう 思う（5)」から「全くそう思わない (1)」までの 5 段階で評定させた。評定項目は,「今後は, 期末 試験で単位を落とさないようにすることができる と思いますか」(試験場面),「次回また，同じよ うなレポートが課されたら，あなたはうまくやれ ると思いますか」（レポート場面）である.

場面の重要性の評定項目 各場面のような状況 について，「どの程度深刻であると思いますか」 との項目に，「非常にそう思う(5)」から「全く そう思わない (1)」までの5 段階で評定させた。 
GSE 尺度 成田ほか（1995）の尺度（23 項目） を使用した。「そう思う(5)」から「そうは思わ ない(1)」までの5 段階で評定させた。評定值が 大きいほどGSEが高くなるように，23 項目の評 定値を集計し，GSE尺度得点とした。

\section{結果と考察}

\section{1. 分析対象者の選定}

原因帰属や対処行動の選択には場面の重要性を 認知しているか否かが影響すると考えられるの で，ある程度，各場面を重要であると認知してい る者のみを分析対象者とすることとした。 そこで, 場面ごとに重要性の評定值が 3 以上の被調查者を 選び出して分析対象者とした。試験場面は 166 名 （男性 59 名，女性 107 名)，レポート場面は 166 名（男性 61 名，女性 105 名）であった。このう ち，両場面ともに分析対象となったのは，145名 （男性 51 名，女性 94 名）であった（試験場面の 分析対象者の $87 \%$, レポート場面の分析対象者 の $87 \%$ ，両場面でかさなっている)。なお, 以 下の分析では, 原因帰属評定項目・対処行動評定 項目・SSE 評定項目・重要性評定項目の各評定
値，および，GSE 尺度得点を便宜的に間隔尺度 上の得点とみなして処理した。評定值の平均值や 評定值間の相関には以下に詳述するような性差が みられており，また，評価的な（ポジティブ， あ るいはネガティブな）結果に対する原因帰属には, 性差が存在することを示す先行研究 (Beyer, 1999/ 1998）もあることから，分析は男女別に行なった.

\section{GSEによる SSEの違い}

まず，GSEの高低により SSE に差がみられる という，三宅 (2000) と同様の結果が得られてい るかどうかを確認する，場面ごとに分析対象者の GSEの平均值を境いに GSE 高群と GSE 低群に分 け, GSE 群別に SSEの平均值を算出し, 平均值 の差の検定（ $t$ 検定）を行なった。結果は, Table 2 と Table 3 に示す。すべて GSE 高群の SSE の評定值は SSE 低群よりも高く，その差は，試 験場面の男性のデータを除き有意であった。また， 場面別に GSE とSSE との相関係数を求めると, 試験場面では，男性で $r=.16(n s)$ ，女性で $r=.40$ $(p<.001)$ ，レポート場面では，男性で $r=.38$ $(p<.01)$, 女性で $r=.46(p<.001)$ であった.こ

Table 2 GSE群別の試験場面におけるSSE, 原因帰属, 対処行動の評定値の平均值（( )内は標準偏差)

\begin{tabular}{|c|c|c|c|c|c|c|}
\hline & \multicolumn{3}{|c|}{ 男性 } & \multicolumn{3}{|c|}{ 女性 } \\
\hline & $\begin{array}{c}\text { GSE 高群 } \\
n=28 \\
84.36^{\mathrm{a})}[104-74]^{\mathrm{b})} \\
\end{array}$ & $\begin{array}{c}\text { GSE 低群 } \\
n=31 \\
65.45[73-45] \\
\end{array}$ & $\begin{array}{l}\text { 群間差 } \\
(t \text { 值 })\end{array}$ & $\begin{array}{c}\text { GSE 高群 } \\
n=53 \\
81.72[100-74] \\
\end{array}$ & $\begin{array}{c}\text { GSE低群 } \\
n=54 \\
62.94 \text { [73-37] } \\
\end{array}$ & $\begin{array}{l}\text { 群間差 } \\
(t \text { 值 })\end{array}$ \\
\hline $\begin{array}{l}\text { SSE } \\
\text { 原因帰属 }\end{array}$ & $3.54 \quad(1.20)$ & 3.32 (1.05) & 0.73 & $3.49 \quad(0.95)$ & $3.07 \quad(0.82)$ & $2.42^{*}$ \\
\hline 努力 & $4.11 \quad(0.96)$ & $3.74 \quad(1.12)$ & 1.34 & 3.74 (1.04) & $4.06 \quad(0.88)$ & $1.72^{+}$ \\
\hline 取り組み方 & 3.68 (1.02) & $3.61 \quad(1.02)$ & 0.25 & $3.62 \quad(0.95)$ & $3.77 \quad(0.86)$ & 0.89 \\
\hline 能力 & $3.21 \quad(1.42)$ & $2.61 \quad(1.00)$ & $1.90^{+}$ & $3.00 \quad(0.96)$ & 3.37 (1.01) & $1.94^{+}$ \\
\hline 課題 & $2.93(0.98)$ & $3.13 \quad(1.09)$ & 0.74 & $3.06 \quad(0.91)$ & 3.13 (1.05) & 0.39 \\
\hline 運 & 2.68 (1.06) & 3.13 (1.18) & 1.54 & 2.89 (1.01) & 2.74 (1.07) & 0.73 \\
\hline 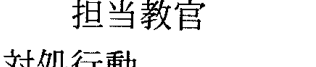 & $2.29 \quad(1.30)$ & $3.42 \quad(1.26)$ & $3.40^{* *}$ & $2.53 \quad(1.07)$ & $2.26(0.89)$ & 1.41 \\
\hline 対処行動 & & & & & & \\
\hline 積極的対処行動 & $10.79 \quad(2.53)$ & $8.23 \quad(1.94)$ & $4.38^{* * *}$ & $10.02 \quad(2.32)$ & $9.09 \quad(2.27)$ & $2.09^{*}$ \\
\hline 消極的対処行動 & $7.93 \quad(3.07)$ & $9.87 \quad(2.17)$ & $2.83^{* *}$ & $9.32 \quad(2.00)$ & $9.98 \quad(2.27)$ & 1.60 \\
\hline
\end{tabular}

$* * * p<.001, \quad * * p<.01, * p<.05, \quad+p<.10$

a) GSE尺度得点の平均值 b) GSE尺度得点のレンシ 
Table 3 GSE群別のレポート場面におけるSSE，原因帰属，対処行動の評定值の平均值（( )内は標準偏差）

\begin{tabular}{|c|c|c|c|c|c|c|}
\hline & \multicolumn{3}{|c|}{ 男性 } & \multicolumn{3}{|c|}{ 女性 } \\
\hline & $\begin{array}{c}\text { GSE 高群 } \\
n=30 \\
85.10^{\text {a) }}[104-75]^{\text {b) }} \\
\end{array}$ & $\begin{array}{c}\text { GSE低群 } \\
n=31 \\
65.26 \text { [74-45] }\end{array}$ & $\begin{array}{l}\text { 群間差 } \\
(t \text { 値 })\end{array}$ & $\begin{array}{c}\text { GSE 高群 } \\
n=52 \\
82.90[100-75]\end{array}$ & $\begin{array}{c}\text { GSE 低群 } \\
\quad n=53 \\
64.40[74-37] \\
\end{array}$ & $\begin{array}{l}\text { 群間差 } \\
(t \text { 値 }) \\
\end{array}$ \\
\hline SSE & $4.03 \quad(0.96)$ & $3.16 \quad(0.93)$ & $3.59^{* * *}$ & $3.42(0.91)$ & $2.96(0.96)$ & $2.52^{*}$ \\
\hline \multicolumn{7}{|l|}{ 原因帰属 } \\
\hline 努力 & $4.33 \quad(0.88)$ & $3.84 \quad(0.97)$ & $2.08^{*}$ & $3.54 \quad(1.02)$ & $3.98 \quad(0.93)$ & $2.33^{*}$ \\
\hline 取り組み方 & $3.97 \quad(0.96)$ & $3.55 \quad(0.89)$ & $1.76^{+}$ & $3.56 \quad(0.96)$ & 3.75 (1.04) & 1.01 \\
\hline 能力 & $3.27 \quad(1.14)$ & $2.90(1.08)$ & 1.28 & $3.10(1.00)$ & $3.53 \quad(0.91)$ & $2.32^{*}$ \\
\hline 課題 & 2.47 (1.04) & $2.97 \quad(1.02)$ & $1.90^{+}$ & $2.79(0.87)$ & $3.21 \quad(0.95)$ & $2.36^{*}$ \\
\hline 運 & $2.10(1.06)$ & $2.61 \quad(1.17)$ & $1.79^{+}$ & $2.46 \quad(0.98)$ & $2.30(1.07)$ & 0.80 \\
\hline 担当教官 & $2.30(1.06)$ & 2.87 (1.18) & $1.99^{+}$ & 2.35 (1.15) & $2.38 \quad(0.86)$ & 0.16 \\
\hline \multicolumn{7}{|l|}{ 対処行動 } \\
\hline 積極的対処行動 & $11.57(2.18)$ & $9.10 \quad(2.31)$ & $4.29^{* * *}$ & 10.37 & $9.77 \quad(2.58)$ & 1.18 \\
\hline 消極的対処行動 & $6.67 \quad(2.52)$ & $8.23 \quad(2.00)$ & $2.68^{* *}$ & $8.04 \quad(1.90)$ & $8.30 \quad(1.92)$ & 0.71 \\
\hline
\end{tabular}

$* * * p<.001, * * p<.01, \quad * p<.05, \quad+p<.10$

a) GSE尺度得点の平均值 b) GSE尺度得点のレンジ
れより，GSEが高い者ほど，ネガティブな フィードバックを受けた後でも次回に対する SSE は高くなっていることが本研究でも確認された。 ただし，男性の試験場面においては，高群・低群 間の平均値の差も, GSE と SSE との間の相関係 数も有意なほどではなかった，本研究では，SSE において GSE 群間差がみられることが前提条件 なので，群間差の有意なものとそうでないものは 別に分析する必要があろう. そこで以下の分析 は場面別に行なうこととする.

\section{GSEによる原因帰属と対処行動の違い}

Table 2, Table 3 に, SSEの他に, GSE 群別の 原因帰属之対処行動の評定値の平均值と, GSE 群間の平均値の差の検定（ $t$ 検定）結果を示す. 対処行動の評定值については, 性別, 場面別に因 子分析（初期解を主成分解とし, バリマックス回 転を使用）を行なった. その結果, 固有值の值と その推移のし方から，2因子解が適当であると解 釈され（2因子による累積寄与率は，56.9から $59.4 \%)$ ，「嫌なことなのであまり深く考えないよ うにする」項目が両因子に負荷する傾向はみられ
たが，積極的対処行動に関する 3 項目と消極的対 処行動に関する 3 項目とにまとまる傾向がみられ た。そこで，それぞれの評定值の和を，積極的対 処行動, 消極的対処行動の評定值として使用した. これらの結果から，GSEの高さによる原因帰属 と対処行動の違いに関して, 以下のようなことが 示された.

男性では，試験場面（Table 2) において，全 体的に GSE 高群の方が内的な要因により強く帰 属し, GSE 低群の方が外的な要因により強く帰 属する傾向がみられた。このうち，群間差が有意 であったのは，「担当教官」であり，GSE 低群の 方が「担当教官」へ強く帰属していた。また， 「能力」には GSE 高群の方が強く帰属する傾向が みられた。一般に，ネガティブな結果を内的で統 制不可能な要因である「能力」へ帰属することは 次回に対するSSEを低めると予想されるが，こ の場合, 能力における群間差は, GSE 低群の自 己保護的な帰属傾向（ネガティブな結果を，自己 内の要因には帰属しようとせず，自己外の要因に 帰属しようとする傾向）のために生じたと考えら れる.すなわち, 試験場面の分析対象者の平均値 
と標準偏差を用いて, 両群の評定值を標準得点化 したところ,「努力」,「取り組み方」,「能力」, 「課題」,「運」,「担当教官」の順に, GSE 高群で は, $0.20,-0.00,0.12,-0.14,-0.16,-0.24, \mathrm{GSE}$ 低群では，-0.16, - 0.07, - 0.43, 0.06, 0.26, 0.73 であった. GSE 低群では「担当教官」への帰属 が極端に高く,「能力」への帰属が極端に低いこ とがわかる，このことから，GSE 低群が自己保 護的な帰属バイアスをより強くもっていたため, 「能力」における GSE 群間差の傾向が生じたと考 えられる。また，GSE尺度得点と原因帰属の各 項目には，GSEと「担当教官」，「能力」との間 に，それぞれ，r=-.49 $(p<.001), r=.32(p<.05)$ の相関係数がみられたが, SSE 評定値との間に有 意な相関を持つ原因帰属の項目はなかった。この 場面では GSEの高低によるSSEの差は有意では なく，GSE 群間の帰属パターンの差もさほど明 確に現われているとは言い難い。一方，対処行動 の評定值には, 積極的対処行動においては GSE 高群の評定值が有意に高く, 消極的対処行動にお いては GSE 低群の評定值が有意に高いという明 確な群間差がみられており，GSE 高群は積極的 対処行動を, GSE 低群は消極的対処行動をとる 傾向が強いことが示された。

男性のレポート場面（Table 3）においても, GSE 高群の方が内的な要因に, GSE 低群の方が 外的な要因により強く帰属させる傾向がみられ, この傾向は試験場面よりも顕著であった。このう ち群間差が有意であったのは，「努力」であり， GSE 高群の方が「努力」へより強く帰属させて いたままた，「取り組み方」には，GSE 高群の方 が強く帰属させる傾向が,「課題」,「運」,「担当 教官」には, GSE 低群の方が強く帰属させる傾 向がみられた，GSE 尺度得点と原因帰属の各項 目との相関は,「努力」との間の相関係数 $(r=.30, p<.05)$ は有意で,「運」,「担当教官」と の間の相関係数（それぞれ， $r=-.25, p<.10$; $r=-.24, p<.10 ＼mathrm{~ も 有 意 と な る 傾 向 か ゙ み ら れ た . ~}$
一方, SSE 評定值と原因帰属の各項目との間の相 関については,「課題」との間の相関係数 $(r=-.34, p<.01)$ が有意であった，SSEにおける GSE 群間差には，これらの帰属傾向の違いが影 響していると考えられる，すなわち，内的で統制 可能な要因である「努力」と「取り組み方」へよ り強く帰属している GSE 高群は，外的な帰属因 である「課題」,「運」,「担当教官」へより強く帰 属する傾向のある GSE 低群に対し，明らかに適 応的な帰属傾向を示しており，この帰属傾向の差 が GSE 高群と GSE 低群との間の SSE の差をもた らしたと推測される．対処行動の評定值にも試験 場面と同様の明確な GSE 群間差がみられ，積極 的対処行動においては GSE 高群の評定值が有意 に高く, 消極的対処行動においてはGSE 低群の 評定值が有意に高い。この場面では，予想通り， GSE 高群は GSE 低群と比較して，内的で統制可 能な要因である「努力」や「取り組み」への帰属 が強く, 積極的対処行動をとる傾向も強いという パターンが示された，加えて，消極的対処行動を とる傾向は GSE 低群よりも低いことも示された.

次に, 女性の試験場面（Table 2）においては, 「課題」への帰属を除き, GSE 高群は外的な要因 に，GSE 低群は内的な要因に比較的強く帰属す る傾向がみられた。群間差は有意なほどではな かったが，「能力」と「努力」にGSE低群の方が より強く帰属する傾向がみられた。また, GSE 尺度得点亡原因帰属の各項目との相関を見ると, 「運」との間の相関係数 $(r=.22, p<.05)$ 法有意 で,「努力」との間の相関係数 $(r=-.19, p<.10)$ も有意となる傾向がみられた，GSEが高いほど 「運」への帰属は強く, 「努力」への帰属は弱い傾 向がある．また，SSE 評定值と「運」との間の相 関係数 $(r=.27, p<.01)$ が有意で,「運」へ強く 帰属するほど SSEが高くなる傾向がみられてい た.この場合は, SSEにおける GSE 群間差には, GSE 高群がネガティブな結果を自己外の要因に, GSE 低群がネガティブな結果を自己内の要因に, 
より強く帰属したことが影響していたと推測され る. 内的で統制可能な要因である「努力」への帰 属は, 一見, 努力量の増加をもたらす適応的な帰 属傾向のようであるが，この場合は同時に「能力」 の評定値も高く，統制不可能な要因である「能力」 の不足とセットになった「努力」への帰属は，努 力しても能力がないためどうにもならないという 絶望的な状態であるとも解釈できる. 対処行動に ついては, 男性の試験場面およびレポート場面と 同様に, 積極的対処行動の評定値は GSE 高群の 方が有意に高かった。一方, 消極的対処行動の評 定値は，GSE低群の方が数值は低いが群間差は 有意ではなかった。 ネガティブな出来事を自己内 の統制不可能な原因である「能力」により強く帰 属するGSE低群の帰属傾向は, 事態への能動 的・積極的な対処にはつながりにくいという意味 で，不適応的な帰属傾向と考えられる。それに対 し，ネガティブな出来事を自己に帰属しない GSE 高群の帰属傾向は, 相対的に, 積極的な対 処行動をとろうとする意欲を䘫失しにくいもので あり，積極的な対処行動における群間差をもたら したのであろう。男性の GSE 高群においては適 応的な帰属傾向がSSEの高さや積極的な対処行 動につながると考えられるのに対し，女性におい ては GSE 高群が低群ほど不適応的な帰属傾向を もたないこと，すなわち，相対的に自己保護的な 帰属傾向をもっていることが, GSE 群間のSSE や対処行動の差につながつていると考えられる. 男性の GSE 高群における, 対処行動および SSE の評定值と, 女性の GSE 高群のそれらを見比べ ると, 男性のほうが積極的対処行動とSSEの評 定値が高く，女性のほうは消極的対処行動の評定 值が高めであるが，そこには男女間の原因帰属傾 向の違いが関連している可能性が推測される.

女性のレポート場面（Table3）においては, 「運」を除くすべての要因について, 低群の評定 值が高くなっていた。このうち群間差が有意で あったのは, 「能力」,「努力」,「課題」であった.
GSE 尺度得点と原因帰属の各項目との相関を見 ると,「能力」,「運」との間の相関係数が有意で, それぞれ，r=-.26 $(p<.01), r=.20(p<.05)$ で あり, GSEが高いほど「能力」への帰属が弱く, 「運」への帰属が強い。また, SSE 評定值と原因 帰属の各項目との間の相関係数は,「取り組み方」 において有意で $(r=.21, p<.05)$ ，「取り組み方」 に強く帰属するほどSSEは高くなっていた。ま た「運」との間の相関係数 $(r=.17, p<.10)$ も有 意となる傾向がみられた，GSE 低群では，GSE 高群に比べ, 統制不可能な要因である「能力」, 「課題」へより強く帰属していることがSSEを低 下させていると考えられる，ここでもまた，GSE 低群における内的で統制可能な要因である「努力」 への帰属は, 同時に「能力」, 「課題」の評定值も 高めであることから，必ずしも適応的な帰属傾向 であるとはいえない. 対処行動の評定值には大き な GSE 群間差はみられていないが，女性の試験 場面と同様に, SSEにおける GSE 群間差が GSE 低群の不適応的な帰属傾向（或いは，GSE 高群 の自己保護的な帰属傾向）によるものである場合 には，対処行動には GSE 群間差は見受けられに くいようである.

以上の結果から, 男性の場合, SSEにおける GSE 群間差は GSE 高群の適応的な帰属傾向（内 的で統制可能な要因への原因帰属)により生じて いると考えられる，一方，女性の場合，SSEにお ける GSE 群間差は，GSE低群の不適応的な帰属 傾向（あるいは GSE 高群の自己保護的な帰属傾 向）の結果として生じたものであると考えられる. つまり，GSE高群に対して予想された，2タイプ の帰属傾向（内的で統制可能な要因へより強く帰 属する傾向と, より自己保護的な帰属傾向）の両 方が見出されたのである.

また, 本研究の結果からは, それらの 2 タイプ の帰属傾向が性差と関わることが示唆されるが, その背景として達成動機や成功回避動機における ジェンダー差が考えられる，すなわち，成功や失 
敗に対する原因帰属には性役割意識に基づく性差 がみられ，試験の失敗のようなネガティブな結果 に対し，概して，男性が次回の期待を高める（低 めない）ような不安定で統制可能な要因へ原因を 帰属するのに対し，女性は能力や課題の難しさと いった次回の期待を低めるような要因への帰属を 行なう傾向が知られている (Beyer, 1999/1998). 本研究でみられた，男性および女性の帰属傾向の GSE 群間差には，ジェンダー差に関する研究で 見出された男性の帰属傾向，女性の帰属傾向との 対応がみられ，そのような文化的な背景の影響が 示唆される，ただし，本研究ではこれらについて 積極的に検討してはいないのでジェンダーによる 差であるといえるかどうかの検討も含め, 今後の 研究にゆだねられる。

ところで, 本研究で扱つた, 「積極的対処行動」 と「消極的対処行動」との間には, 試験場面では, 男性において $r=-.43(p<.001)$ ，女性において $r=-.23(p<.01)$, また，レポート場面では，男 性において $r=-.25(p<.10)$ ，女性において $r=-.10(n s)$ の相関が見られている.これより, 両者の間には一方が高いと他方が低くなる傾向は 見られるが，必ずしも両者が二者択一的な関係に あるものではないことがうかがわれる.

最後に，今回使用した試験場面では，男性の SSEに有意な GSE 群間差が見出されなかった. これは, 試験場面が行動と結果の随伴を感じにく い場面であり，場面に対する統制可能性の認知に, GSEの高低の効果が生じにくかったためと考元 られる，すなわち，両場面で重要性を 3 以上に評 定した者（男性 51 名，女性 94名）を対象に，各 帰属評定項目について, 性別に, 対応のある $t$ 検 定を行なった結果, 男性では課題 $(t=2.70, d f=$ $50, p<.01)$ と運（ $t=3.96, d f=50, p<.001 ）$ にお いて, 女性では運 $(t=4.78, d f=93, p<.001)$ に おいて，場面間の差が有意で，レポート場面より 試験場面のほうが課題の困難さや運の悪さが強く 影響していると感じていることが示された，運の
悪さの影響が強く認知されていることから，試験 場面はレポート場面に比べ遂行とその結果の間の 必然的な結びつきが感じられにくい場面であった ことが示唆される．このことが，統制可能性の認 知の程度により生じていると考えられる, 男性の SSEにおけるGSE 群間差をみられにくくしたの であろう，今後は，結果に影響を及ぼす可能性の ある場面の性質にも十分留意して検討を進める必 要がある.

\section{引用文献}

Bandura, A. 1977 Self-efficacy: Toward a unifying theory of behavioral change. Psychological Review, 84, 191-215.

Bandura, A. 1986 Social foundations of thought and action: A social cognitive theory. Englewood Cliffs, NJ: Prentice-Hall.

Beyer, S. 1999/1998 Gender differences in causal attributions by college students of performance on course examinations. Current Psychology: Developmental Learning Personality Social, Winter, 17, 346-358.

Forsyth, D. R., \& McMillan, J. H. 1981 Attribution, affect and expectations: A test of Weiner's threedimensional model. Journal of Educational Psychology, 73, 393-403.

藤田 正・笹川宏樹 1991 女子学生における一般 性 self-efficacy と locus of control の関係 奈良教育 大学教育研究所紀要, 27, 115-121.

Hayamizu, T. 1997 Between intrinsic and extrinsic motivation: Examination of reasons for academic study based on the theory of internalization. Japanese Psychological Research, 39, 98-108.

三宅幹子 2000 特性的自己効力感が課題固有の自 己効力感の変容に与える影響—課題成績の フィードバック操作を用いて 教育心理学研究, 48, 42-51.

成田健一 - 下仲順子 - 中里克治 - 河合千恵子 - 佐藤 眞一・長田由紀子 1995 特性的自己効力感尺度 の検討一生涯発達利用の可能性を探る 教育心 理学研究, 43, 306-251.

Rotter, J. B. 1966 Generalized expectancies for internal versus external control of reinforcement. Psychological Monographs: General and Applied, 80, 1-28. 坂野雄二 1989 一般性セルフ・エフィカシー尺度 
の妥当性の検討 早稲田大学人間科学研究, $2,91-$ 98.

坂野雄二・東條光彦 1986 一般性セルフ・エフィ

カシー尺度作成の試み 行動療法研究, 12, 73-82.

坂野雄二・東條光彦 1993 セルフ・エフィカシー尺

度 上里一郎 (監修) 心理アセスメントハンドブッ

ク 西村書店 Pp.478-489.

Sherer, M., Maddux, J. E., Mercandante, B., PrenticeDunn, S., Jacobs, B., \& Rogers, R. W. 1982 The selfefficacy scale: Construction and validation. Psychological Reports, 51, 663-671.
Silver, W. S., Mitchell, T. R., \& Gist, M. E. 1995 Responses to successful and unsuccessful performance: The modeling effect of self-efficacy on the relationship between performance and attributions. Organizational Behavior and Human Decision Processes, 62, 286-299.

Watt, S. E., \& Martin, P. R. 1994 Effect of general selfefficacy expectancies on attributions. Psychological Reports, 75, 951-961.

- 1999. 12. 6. 受稿, 2000. 6. 6. 受理一

Motoko Miyake (Graduate School of Education, Hiroshima University). Effects of generalized self-efficacy on causal attribution and coping behavior for negative events. THE JaPANESE Journal of Personality 2000, Vol.9 No.1, 1-10.

This study examined the effects of generalized self-efficacy (GSE) on causal attribution and coping behavior for negative events. Two negative events were described, and for each of them, 238 undergraduates were asked to imagine themselves being faced with the event, and rate the likelihood of six probable causes for it, how likely that they would adopt each of nine coping behaviors, their specific self-efficacy (SSE) to prevent it next time, and its seriousness. In addition, they filled a GSE scale. For each event, 166 students rated its seriousness as fairly to very serious, and were selected for further analysis. Results showed different patterns for men and women. Men with high GSE attributed the negative event more to internal and controllable causes, and less to external ones than those with low GSE. On the other hand, women with high GSE attributed it less to internal causes than those with low GSE. Both men and women with high GSE showed a higher SSE, and adopted more active coping behavior.

Key words : generalized self-efficacy, negative events, causal attribution, coping behavior 